Published in European Romantic Review 23 (2012): 305-11. Please cite published version.

\title{
Telling Stories About Romantic Theory
}

Nicholas Halmi*

Faculty of English, University of Oxford, Oxford, UK

The invitation to participate in the seminar on Theory was simultaneously pleasing and puzzling: I was pleased to be paired with Tilottama Rajan, towards whose work I am intellectually sympathetic, but puzzled by the rubric under which I was asked to articulate the relation of my Genealogy of the Romantic Symbol to her Dark Interpreter. My only contributions to what is conventionally understood in literary studies as Theory have been an article on Northrop Frye and one on Walter Benjamin's epistemological preface to the Origin of German Tragic Drama ("Walter"). And the latter, having been commissioned by and published in a South Korean journal, remains almost entirely unknown anywhere else. For its part the Genealogy makes little reference to contemporary literary theory, and thereby largely excludes itself from the principal discursive context in which the Romantic conception of the symbol has been a focus of attention. But this self-exclusion was partly a consequence of what Rajan calls the book's "reconstruction" of the Romantic symbol in its public intellectual context. For in that context the symbol appears not as an actual semiotic, still less a specifically literary, phenomenon, but as a philosophical construct that sought discursively to institute, in Gadamer's sense of the term, a mode of non-discursive representation inhering in the structure of the world itself. In other words, the symbol was a concept as defined by Reinhart Koselleck: that is, a model of a structure of relationships, in this case of a paradoxical fusion of presence and reference.

\footnotetext{
*Email: nicholas.halmi@ell.ox.ac.uk
} 
However perverse my choice of subject might have been — and in professional terms it doubtless was perverse - my decision to isolate that subject from literary criticism was consistent with the aim of recovering the historicity of the Romantic symbol. It is true that Gadamer had long ago recognized that for Goethe the symbol involved "not so much an aesthetic experience as an experience of reality [eine Wirklichkeitserfahrung]" (82), and that Schelling, whose own theorization of the symbol was strongly influenced by Goethe in the years of their personal contact (1798-1803), had self-contradictorily demonstrated the uncontainability of the symbol within the schemata of a taxonomical aesthetics. But it is also true that Schelling had adopted from Goethe and bequeathed to others (including, albeit indirectly, Coleridge) the invidious distinction between symbol and allegory-a distinction that, although neither widely nor consistently maintained in German Romanticism itself, has of course been the object of much contention in literary criticism of the last half-century.

What was originally at stake in this distinction was not the desynonymization of dissimilar kinds of poetic imagery, but the differentiation of inherent and objective significance from arbitrarily constituted signification, of which allegory (especially in the debased form widely practised in the eighteenth century) served as a convenient example. So the symbol was an aesthetic concept, but in the service of a philosophical aestheticization of the world. The contrast with allegory, however, misleadingly fostered the assumption that the theorists of the symbol were seeking to clarify figurative representation. Calling that assumption into question was the point of departure for my book, which in that respect is theoretical in the broadest, though still distinctively modern sense, to which I shall return in my conclusion.

But in what does the affinity of the Genealogy with Dark Interpreter consist? One is signalled in the "Freudian slip," as Rajan calls it, by which the conference organizers have metonymically identified Theory with German philosophy (Rajan, "Unfinished” ). Neither 
book, it should be emphasized, treats German philosophy as an autonomous object of study. In asserting the relevance of philosophy to literary criticism, Dark Interpreter adumbrated what became a central concern of Rajan's subsequent work, namely the development of twentieth-century Theory precisely from Romantic, and particularly German Romantic, philosophy. In re-establishing the philosophical character of the symbol, the Genealogy suggested the role of German Romantic philosophy in modernity's confrontation with its self-created discontents.

But the differences between our respective engagements with that philosophy will be more immediately evident. It could not assist me, as it could Rajan, in thinking beyond the conceptual paradigms of Romantic studies, for the concept of the symbol was itself first formulated systematically in German Idealism. In order to explain how such a concept could not only have emerged but acquired considerable intellectual urgency, I had to investigate the networks of direct and indirect contacts, public and private discussions, and works published and read that constituted what Dieter Henrich describes as the Jena "constellation" of German Idealism. This investigation therefore required a critical distance from the systematic concerns and conceptual categories of the early Romantic philosophers, a distance that, as I shall elaborate momentarily, I established without, as it were, leaving Germany.

In retrospect I wish I had found some way to adopt, in effect, the reverse of the procedure by which Rajan sought to approach English Romanticism in Dark Interpreter: that is, by applying the critical vocabulary of English Romanticism to its German counterpart. Admittedly Coleridge, who after Schelling is the figure discussed most extensively in the Genealogy, might have presented challenges to such a procedure, to the extent that he departed from his German contemporaries in appropriating language from radically heterogeneous philosophical and theological sources to describe the symbol. But perhaps the book would have attracted a wider readership if I had exploited methodologically my own 
recognition that "the symbolist theory of the philosophically minded Romantics, for the most part Germans, was closely related to the poetic project of English writers like Wordsworth and Shelley" (Genealogy 24).

Certainly I agree with Rajan's claim in Dark Interpreter that the German Romantic theorists and the English Romantic poets shared a profound ambivalence about the limits of their idealism (29). Indeed the implicit purpose of my refusal to concede a distinctive Englishness to Coleridge's theorization of the symbol was to throw into relief exactly the transnational commonality of Romantic uncertainty about the epistemological status of signification in general, an uncertainty to which the postulation of a signification without intentionality provided, however briefly and inadequately, a theoretical antidote. This de facto assimilation of Coleridge to the Germans seemed to me justified both on its own terms and in the interest of counteracting the tendency in anglophone criticism, beginning of course with that by Coleridge's contemporaries, to dismiss his relation to German philosophy as extraneous to his most fundamental concerns and essential intellectual character. The limited degree of my success in that respect can be gauged from those reviews-happily a minority — that treated the Genealogy as if it were solely about Coleridge.

In the event, what was clear to me from the outset of the book's long gestation was that I could follow neither of the critical paths I had been shown as an undergraduate at Cornell, where M. H. Abrams himself introduced me to the argument of Natural Supernaturalism (mine must have been one of the last classes he taught) and Cynthia Chase introduced me to Paul de Man's essays on Romantic poetry (a year or two before the rediscovery of his wartime writings). Like Dark Interpreter, if for different reasons, the Genealogy explicitly registers dissatisfaction with the alternatives presented by Abrams's logocentric intellectual history and de Man's deconstructive rhetorical analysis: one uncritically affirming Romantic idealism, the other tendentiously overemphasizing Romantic 
irony. From either perspective it would have been impossible to elaborate my basic argument that, although self-mystified, the symbol was not (pace de Man) a trope, and that, although a concept, it was not (pace Abrams) a philosophically sublimated remnant of Christian theology.

In sum, both Natural Supernaturalism and "The Rhetoric of Temporality" were insufficiently historical for my purposes. While Abrams's book, as Hillis Miller observed in his review of it (8), treated analogously structured systems of thought as equivalent in content, and thereby obscured their historical specificity, de Man's essay presupposed the contextual function of Romantic theorizations of representation, and thereby precluded interrogation of exactly that function. Semiotics too (as opposed to Foucault's archaeology of Enlightenment semiotics in The Order of Things) was of limited use because its systematic concern is with the pragmatics of signification itself rather than with the historical development of particular semiotic models. Thus the encounter with Begriffsgeschichte, the philosophically grounded but interdisciplinary practice of conceptual history represented by Erich Rothacker, Joachim Ritter, Reinhart Koselleck, and (to an extent) Hans Blumenberg, among others, proved methodologically decisive for me. Neither exclusively internalist in focus (like the history of philosophy) nor indifferent to systematic considerations (like a culturally oriented historicist criticism), Begriffsgeschichte suggested a means of explaining both the historical attraction and the logical impossibility of the Romantic symbol. The book's title refers partly to what Hans Ulrich Gumbrecht has defined as the "genealogical function" of conceptual history: "clarifying the hidden implications and recuperating the forgotten semantic potential of notions in current systematical use" ("Everyday-World" 447). ${ }^{1}$

In a sense, however, and although I was not fully aware of the fact when writing the Genealogy, the critical method that recommended itself to me-albeit with qualifications to be mentioned presently — had originated within Romanticism itself. Insofar as it presupposes 
a frame of reference in which conceptual and semantic change becomes visible as temporal discontinuity, Begriffsgeschichte is a genealogical product of the historical self-consciousness that Koselleck, for one, identified as having developed in what he called the Sattelzeit, or "saddle period," between roughly 1750 and 1850 ("On the Need" 3-4) —in short, the Romantic period in Europe. This self-consciousness, which I have discussed more recently in connection with the Romantic aestheticization of ruins ("Ruins"), manifested itself in a denaturalized understanding of the relation of the present to the past, and consequently demanded the assessment of historical phenomena in their distinctiveness rather than with reference to an existing and temporally closed narrative of either a providential linearity or an exemplary cyclicality (analogous to seasonal change and planetary motion). Thus in appropriating the tools of Begriffsgeschichte, as well as some of the concepts of the philosophical anthropology with which that historical school was allied (through Rothacker and Blumenberg in a line of descent from Herder), I was paradoxically being more thoroughly Romantic than Abrams, whose vindication of Romantic idealism effectively denies it its historicity. How appropriate to be writing about the symbol, that figureless figure of synecdoche, for my critical distancing from Romanticism was itself synecdochically involved in it. Rajan speaks of the mirror in which Perseus looks indirectly at the Gorgon: for me the Denkraum or conceptual space of German Romanticism was more like a mirrored panopticon in which my critical gaze was reflected distortedly back upon myself.

Notwithstanding its rejection of the semiotic viability of the Romantic symbol, the Genealogy is in fact deeply implicated in Romantic philosophy in two respects, one of which, the conceptually oriented attention to historical discontinuities, I have just mentioned, and the other of which, a concern with system as the organization of knowledge, Rajan has justly identified as the most significant commonality between her work and mine. If that concern remains largely implicit in Dark Interpreter, it is articulated more explicitly in The 
Supplement of Reading, where Rajan follows Dilthey in relating the reading practices theorized in Schleiermacher's hermeneutics to Goethe's scientific studies and post-Kantian idealism more generally $(8,208-9)$, and it is unfolded more comprehensively in her recent articles on Romantic encyclopedics. My own interest in what Rajan calls the "disseminative interdisciplinarity" of Romantic philosophy, meaning "an encyclopedic thinking which discovers that thought cannot be exhausted in a single discipline or form of thought" ("Philosophy" 6), followed from the fact that the theorists of the symbol were not describing a given phenomenon but defining the conditions under which such a phenomenon might present itself. As a "second-order observation," to use Luhmann's term (55-57), concerned with the understanding of representation, the symbol was conceived as an intervention in those disciplines, particularly aesthetics and Naturphilosophie, through which first-order observation of the world of objects was organized: hence the concept's appearance in Schelling's Von der Weltseele (1798), one of his early attempts to elaborate a theory of life, as well as in his Philosophie der Kunst (1802-3), a series of lectures on aesthetics.

Recovering the historicity of the concept of the symbol required recognizing its role in the self-reflexive Romantic systematization of knowledge — a project that was philosophized in the encyclopedic work of Schelling, Novalis, and Coleridge, among others (as Rajan mentions in her seminar paper and discusses elsewhere), and aestheticized in the short-lived program of a "new mythology" (as I discuss in the last chapter of Genealogy).

Yet the genealogical task I had set myself could not be exhausted by confirming that the symbol was not, in de Man's words, "a 'solution' to the problem of metaphorical diction" (176). Such confirmation still left open the question of the problem or problems to which the concept of the symbol might have seemed like the solution. Since the concept itself was related to the organization of knowledge more generally in early Romantic philosophy, an explanation of the impetus behind its formulation had to be deduced from the crises of self- 
understanding bequeathed to the Romantics by the Enlightenment. I shall not rehearse what (in chapter 2 of Genealogy) I concluded those specific crises to have been, but merely note that this pre-history of the Romantic symbol bears less resemblance discursively to Begriffsgeschichte, which in practice has tended to restrict its focus to individual concepts and keywords, than to narrative historiography. Perhaps even in this respect Genealogy betrays its own genealogical relation to the epistemological crisis in Romantic-era thought, for as Gumbrecht reminds us in his historicization of second-order observation, narrative offered to nineteenth-century theorists a provisional solution to the problem of integrating multiple representations with distinct frames of reference, a problem created by the disruptive effect of second-order observation on the belief in the stability of referentiality (Production $38-40)$.

But my resort to narrative had less to do with organizing disparate representations than with accounting for the unphilosophical character of a concept that distinguished the meaningful from the meaningless by denying the existence of the latter. Insofar as it establishes causal or other kinds of links (e.g., contextual contiguity) between phenomena, narrative constitutes a form of explanation that is interpretive without being, as Hayden White would claim, wholly fictional (cf. Metahistory 1-42, "Interpretation," "Question" $42-$ 43) - White's critique of historical narrative presupposing, in conformity to its reductive conception of truth as correspondence, the unrealizable ideal of an entirely non-fictional (mirror-image) mode of historical representation (see Carroll). Positing two types of rationality, one of function as well as one of content, I sought to establish narratively that the logical incoherence of the Romantic symbol had a cultural logic, a logic that remained invisible when the concept was viewed from a semiotic or tropological perspective. And in that respect the Genealogy has a greater affinity with the functionalist analysis undertaken in Blumenberg's Legitimacy of the Modern Age than with the definitional exercises of the 
encyclopedic productions of Begriffsgeschichte proper, such as Ritter's philosophical dictionary and Koselleck’s lexicon of historical concepts (Geschichtliche).

The particular narrative that I had to recount was of the supplanting of theoria in its original sense (as contemplation premised on the truth of self-evidence) by theory (as the calling of self-evidence into question), whereas the complementary narrative that Dark Interpreter outlined (without elaborating at length) was of the development of theory into Theory. While neither narrative is teleological, both account for what might be called processes of intellectual enablement. The point of historical and conceptual convergence between Rajan's book and mine is in the German Romantic philosophy which on the one hand, in its theorization of the symbol, left unfinished the restoration of self-evidence to the systematic understanding of the world, and on the other hand, in its ambivalence towards and questioning of its own idealism, inaugurated the genre of self-reflexive and interdisciplinary critical thought that later became professionalized as Theory.

Especially now, as the philosophical foundations of Romanticism are increasingly occluded by the subject's assimilation, for reasons of pedagogical and financial expediency, into the more exclusively anglophone and anglocentric field of nineteenth-century studies, it is worth recovering that originary scene analyzed in different ways by Dark Interpreter and The Genealogy of the Romantic Symbol, the better to theorize current critical paradigms in Romantic studies, attending as self-reflexively as the German philosophers of the Romantic period themselves did to the inevitable open-endedness of all systems of organizing knowledge.

\section{NOTE}

1. Although this function is not unrelated to the Foucauldian denaturalization of discourses, Foucault's own explicit “genealogies," Discipline and Punish (1975) and 
The History of Sexuality (1976-84), with their restrictive understanding of the emergence of historical formations in terms of conflictual forces, did not serve me as methodological models. As Rajan rightly asks, on what grounds can Foucault formalize - and thus in effect depoliticize - power as the transhistorical object of an historicizing genealogical analysis (Deconstruction 230-31)? In this regard Habermas's critique of "the systematically ambiguous use of the category of "power" by Foucault is also to the point (270). The one work of Foucault's that was of direct, if heavily qualified, use to me was the earlier, "archaeological" The Order of Things (1966) — written in a metaphorical style and characterized by an anthropologisme of which, subsequently, The Archaeology of Knowledge announced the necessity of purging itself (Foucault, Archaeology 26).

\section{References}

Abrams, M. H. Natural Supernaturalism: Tradition and Revolution in Romantic Literature. New York: Norton, 1971. Print.

Blumenberg, Hans. Die Legitimität der Neuzeit. Frankfurt: Suhrkamp, 1966. Print. Carroll, Noël. "Interpretation, History, and Narrative." Beyond Aesthetics: Philosophical Essays. Cambridge: Cambridge UP, 2001. 133-56. Print.

de Man, Paul. "The Rhetoric of Temporality." Interpretation: Theory and Practice. Ed. C. S. Singleton. Baltimore: Johns Hopkins UP, 1969. 173-209. Print.

Foucault, Michel. The Archaeology of Knowledge and The Discourse on Language. 1969, 1971. Trans. A.M. Sheridan Smith. New York: Pantheon, 1972. Print.

---. Discipline and Punish: The Birth of the Prison. 1975. Trans. Alan Sheridan. New York: Vintage, 1979. Print. 
---. The History of Sexuality. Trans. Robert Hurley. 1976-84. 3 vols. New York: Vintage, 1978-86. Print.

---. The Order of Things: An Archaeology of the Human Sciences. 1966. New York: Vintage, 1970. Print.

Gadamer, Hans-Georg. Wahrheit und Methode. Vol. 1 of Gesammelte Werke. Tübingen: Mohr, 1986. Print.

Gumbrecht, Hans Ulrich. “Everyday-World and Life-World as Philosophical Concepts: A Genealogical Approach.” New Literary History 24.4 (1993): 745-61. Print.

---. The Production of Presence: What Meaning Cannot Convey. Stanford: Stanford UP, 2004. Print.

Habermas, Jürgen. "Questions Concerning the Theory of Power: Foucault Again.” The Philosophical Discourse of Modernity. Trans. Frederick Lawrence. Cambridge: MIT P, 1987. 266-93. Print.

Halmi, Nicholas. The Genealogy of the Romantic Symbol. Oxford: Oxford UP, 2007. Print. ---. "Ruins without a Past." Essays in Romanticism 18 (2011): 7-27. Print.

---. “Walter Benjamin's Unacknowledged Romanticism.” Lingua Humanitatis 2.2 (2002): 163-82. Print.

Henrich, Dieter. Konstellationen: Probleme und Debatten am Ursprung der idealistischen Philosophie (1789-1795). Stuttgart: Klett-Cotta, 1991. Print.

Koselleck, Reinhart, ed. Geschichtliche Grundbegriffe: Historisches Lexikon zur politischsozialen Sprache in Deutschland. 8 vols. Stuttgart: Klett, 1972-97. Print.

---. "On the Need for Theory in the Discipline of History.” The Practice of Conceptual History: Timing History, Spacing Concepts. Trans. T. S. Presner et al. Stanford: Stanford UP, 2002. 1-19. Print. 
Luhmann, Niklas. Art as a Social System. Trans. Eva Knodt. Stanford: Stanford UP, 2000. Print.

Miller, J. Hillis. “Tradition and Difference.” Diacritics 2.4 (1972): 6-13. Print.

Rajan, Tilottama. Dark Interpreter: The Discourse of Romanticism. Ithaca: Cornell UP, 1980. Print.

---. Deconstruction and the Remainders of Phenomenology. Stanford: Stanford UP, 2002. Print.

---. "Philosophy as Encyclopedia: Hegel, Schelling, and the Organization of Knowledge." The Wordsworth Circle 35.1 (2004): 6-11. Print.

---. "Romanticism and the Unfinished Project of Deconstruction." European Romantic Review 23 (2012): 293-303. Print.

---. The Supplement of Reading: Figures of Understanding in Romantic Theory and Practice. Ithaca: Cornell UP, 1990. Print.

Ritter, Joachim, ed. Historisches Wörterbuch der Philosophie. 13 vols. Basel: Schwabe, 1971-2007. Print.

White, Hayden. "Interpretation in History." Tropics of Discourse: Essays in Cultural Criticism. Baltimore: Johns Hopkins UP, 1978. 51-80. Print.

---. Metahistory: The Historical Imagination in Nineteenth-Century Europe. Baltimore: Johns Hopkins UP, 1973. Print.

---. "The Question of Narrative in Contemporary Historical Theory." The Content of the Form: Narrative Discourse and Historical Representation. Baltimore: Johns Hopkins UP, 1987. 27-57. Print. 